\title{
Precursor-Product Relationships between Nucleotides and RNA during Differentiation in Dictyostelium discoideum
}

\author{
By C. L. RUTHERFORD*, W. Y. KONG, D. PARK \\ AND B. E. WRIGHT \\ Department of Developmental Biology, Boston Biomedical Research Institute, \\ Boston, Massachusetts $021 \mathrm{I} 4$, U.S.A.
}

(Received 8 April $1974 ;$ revised 13 May 1974)

\section{SUMMARY}

Fourteen of the sixteen nucleotides present in extracts of Dictyostelium discoideum were identified by thin-layer chromatography. Data are presented describing the incorporation of radioactive bases into the guanine nucleotide pools and into RNA. Studies with labelled guanine suggested that a small fraction of the RNA undergoes rapid turnover at the pre-culmination stage of differentiation. Analytical methods are described for determining flux rates in vivo and the percentage turnover of endogenous pools.

\section{INTRODUCTION}

We have described previously some aspects of nucleotide metabolism in Dictyostelium discoideum (Rutherford \& Wright, I97I). This report examines the role of nucleotides as precursors for RNA synthesis during differentiation, and demonstrates that an analysis of RNA turnover requires, in addition to a determination of RNA and nucleotide specific radioactivity, kinetic information on the nucleotide precursor pool. Determination of the fluxes and turnover rates in vivo can be complex. Too often these parameters have been calculated from simplified models which represent the flow of radioactivity from precursor to product as would occur in an in vitro system, rather than fully considering the complexities in vivo. In some cases, it is assumed that the rate of incorporation of exogenous radioactive precursors into a macromolecule truly reflects the absolute rate of synthesis (Hirschberg, Ceccarini, Osnos \& Carchman, 1968), but this rate of incorporation rarely reflects synthesis alone and degradation must be considered. Likewise, the macromolecule may be synthesized from only a portion of the soluble precursor pool (Cowie \& Bolton, 1957; Plagemann, I97I, 1972). The addition of labelled precursors may cause changes of the internal pool size or of the intracellular flux rates. The rates of cell growth and division, if they occur, must also be taken into account.

The present investigation was undertaken to consider a number of these possibilities during differentiation in $D$. discoideum and to obtain information about the turnover in vivo of nucleotides and RNA during this process. From the results and those reported earlier (Rutherford \& Wright, I97I), it is apparent that the interpretation of incorporation experiments in vivo may be somewhat simplified in this case because of the unique properties of this organism. During differentiation, Dictyostelium can best be represented as a closed system. There is no requirement for external nutrients, nor is there any cell growth, and the

* Permanent address: Biology Department, Virginia Polytechnic Institute and State University, Blacksburg, Virginia 2406I, U.S.A. 
calculation of intracellular flux rates is therefore not complicated by these variables. The primary internal metabolism of carbohydrates during differentiation is geared toward the conversion of soluble glycogen to new carbohydrates, primarily trehalose and cellulose (Ceccarini \& Filosa, I965; P. A. Rosness and B. E. Wright, unpublished results).

The apparent lack of significant compartmentalization of low molecular weight precursors in $D$. discoideum further simplifies the interpretation of in vivo incorporation kinetics. For example, the lack of significant compartmentalization of the nucleotides UTP, GTP and ATP has previously been shown (Rutherford \& Wright, 197I) and the present analyses provide further evidence. Wright (1968) has developed a kinetic model of carbohydrate metabolism during differentiation based in part upon flux rates in vivo. Flux rates are known for the synthesis and degradation of glycogen (Marshall, Sargent \& Wright, 1970) the synthesis of trehalose (Sargent \& Wright, I97I) and uridine-5'-diphosphoglucose (UDPG) (Pannbacker, 1967), and for the turnover of protein (Wright \& Anderson, 1960). In these cases, no significant compartmentalization of the precursors was apparent, and the resulting flux values were consistent with the observed accumulation of the end products of differentiation (Gustafson \& Wright, 1972).

\section{METHODS}

The harvesting and the conditions of incubation of organisms in the presence of label, and the nucleotide isolation procedures are as described by Rutherford \& Wright, 197I. Compounds isolated by thin-layer chromatography (Randerath \& Randerath, I964a; Rutherford \& Wright, I97I) were identified as follows: (i) Guanine spots were located by exposing the thin-layer sheets to $\mathrm{HCl}$ vapours. This treatment causes guanine nucleotides to exhibit a characteristic blue fluorescence when viewed under u.v. light. Other compounds were tentatively identified by reference to nucleotide maps (Randerath \& Randerath, I $964 \mathrm{~b}$ ). (ii) Ultraviolet absorption spectra of the unknown and authentic compounds. (iii) Incubating organisms in the presence of a labelled base. After chromatography and autoradiography, the compounds containing the radioactive base were detected as dark spots on the X-ray film. (iv) The migration of the unknown compound and an authentic nucleotide during thin-layer chromatography. The unknown spot was cut out and placed in anhydrous methanol for 10 min to remove salt remaining from the first chromatographic solvent. The authentic nucleotide was added and the dry cutout was attached to a fresh thin-layer sheet so that the cellulose layers were in contact. Chromatography was then carried out in $\mathrm{LiCl}$ and formate buffer (Randerath \& Randerath, I964 $b$ ). The identity of the radioactive unknown and authentic compound were determined by comparison of their $R_{F}$ values or by utilizing the finger-print technique (Roberts et al. 1963). Chromatographic separation of the nucleotides was greatly facilitated by cutting the sheet in half after development in the first dimension. Thus, in the second dimension the more polar compounds could be chromatographed in a higher-concentration formate buffer $(4 \mathrm{M}, \mathrm{pH} 3.4)$ and the less polar compounds in a lower-concentration formate buffer $(0.5 \mathrm{M}, \mathrm{pH} 3.4)$.

Specific radioactivities and pool sizes of the nucleotides were determined from their absorbance maxima and radioactivity (LS-200 liquid scintillation counter, Beckman Instruments). Nucleotide concentrations are expressed as mol/l packed cells (Barravecchio, Baumann \& Wright, I969).

Extraction of RNA and determination of the specific radioactivity of $2^{\prime} 3^{\prime}$-GMP resulting from RNA hydrolysis were accomplished by either of two procedures. Organisms (4 ml; $0.4 \mathrm{ml}$ packed volume) were incubated with a labelled precursor for various times. An equal 
volume of cold $7 \%(\mathrm{w} / \mathrm{v})$ perchloric acid (PCA) was then added. After $30 \mathrm{~min}$ in an ice bath, the PCA extract was centrifuged and the supernatant removed for the isolation of acid-soluble nucleotides. The acid-insoluble precipitate was washed with $8 \mathrm{ml}$ of $95 \%(\mathrm{v} / \mathrm{v})$ ethanol to remove the lipids. RNA from the lipid-free residue was hydrolysed with $3.5 \%$ (w/v) PCA at $4{ }^{\circ} \mathrm{C}$ for at least $\mathrm{I} 8 \mathrm{~h}$ and then neutralized with I $\mathrm{N}-\mathrm{KOH}$. Alternatively, the lipid-free residue was suspended in $1.5 \mathrm{ml}$ of $0.3 \mathrm{~N}-\mathrm{KOH}$ and hydrolysed for $18 \mathrm{~h}$ at $37^{\circ} \mathrm{C}$. The solution was acidified by adding $0.15 \mathrm{ml}$ of $35 \%(\mathrm{w} / \mathrm{v}) \mathrm{HClO}_{4}$, centrifuged, and the supernatant neutralized with I N-KOH. The 2' $3^{\prime}$-GMP from the RNA hydrolysates was then isolated by the procedure of Randerath \& Randerath (I965).

The distribution of radioactivity between the organisms and that free in the medium during incubation with labelled bases (New England Nuclear, Boston, Massachusetts, U.S.A.) was determined in samples $(0.2 \mathrm{ml})$ of suspension added to Io $\mathrm{ml}$ aquasol (New England Nuclear). The remainder of a $0.5 \mathrm{ml}$ sample was centrifuged ( $1000 \mathrm{~g}$, I min) and the radioactivity determined in a sample of the supernatant. The radioactivity associated with the organisms was determined by subtraction.

Labelling experiments were routinely done in liquid suspension. However, a comparative study was made under conditions in which differentiation proceeded normally (Newell, Telser \& Sussman, 1969). Millipore absorbant (nutrient) pads ( $42 \mathrm{~mm}$ diam) were saturated with $0 . \mathrm{I}$ M-phosphate buffer (pH 6.5) containing I.O mM-EDTA and placed in $150 \times 25 \mathrm{~mm}$ plastic Petri dishes (Lab-Tek, Westmont, Illinois, U.S.A.). Washed amoebae ( $1 \cdot 5 \mathrm{ml})$ were spread onto Whatman No. 50 filter paper $(9 \mathrm{~cm})$ and placed on the pads. At the desired stage of differentiation the filter papers were transferred to Petri dishes containing absorbant pads saturated with Bonner's (1947) 'standard solution', buffered at $\mathrm{pH} 6.5$ with I.0 mM-2( $N$-morpholino) ethane sulphonic acid and containing a labelled precursor. In other experiments labelled compounds were mixed with I $\mathrm{ml}$ of Bonner's solution, pipetted directly into the Petri dishes, and the filter papers placed in contact with the radioactive solution. At various times filter papers were removed and the organisms washed into test tubes with $8 \mathrm{ml}$ of $3.5 \%$ (w/v) perchloric acid.

\section{RESULTS}

Identification of nucleotides and nucleotide sugars after two-dimensional thin-layer chromatography

Nucleotides and nucleotide sugars were separated by thin-layer chromatography, to determine pool sizes, the amount of radioactive incorporation and their specific radioactivity. Their positions after two-dimensional thin-layer chromatography are shown in Fig. I and by using the criteria described in Methods, I4 of the 16 spots were identified. The pattern shown in Fig. I was found at all stages of differentiation. Spots corresponding to cytosine nucleotides were not observed. The spot just below $\mathrm{NAD}^{+}$was UMP, resulting from the breakdown of UDPG during chromatography in the acidic formate buffer, and its specific radioactivity was always the same as that of UDPG. Furthermore, in chromatograms in which the UDPG spot was relatively dark, little UMP was present; conversely, when the UDPG spot was faint, a dark UMP spot appeared. The spot just below ADP in Fig. I exhibited a brilliant pale-blue fluorescence under u.v. light. Its adsorption spectrum in $0.02 \mathrm{M}$-tris- $\mathrm{HCl} \mathrm{pH} 7.4$ containing $0.7 \mathrm{M}-\mathrm{MgCl}_{2}$ had two major peaks, one at $260 \mathrm{~nm}$, the other, a broad peak, at $365 \mathrm{~nm}$. The fluorescence emission spectrum showed a peak at $460 \mathrm{~nm}$ which was completely destroyed by $\mathrm{HCl}$ at a final concentration of $\mathrm{I} \cdot 2 \mathrm{~N}$. The compound did not co-chromatograph with either NADPH or NADH, nor was it radioactive 

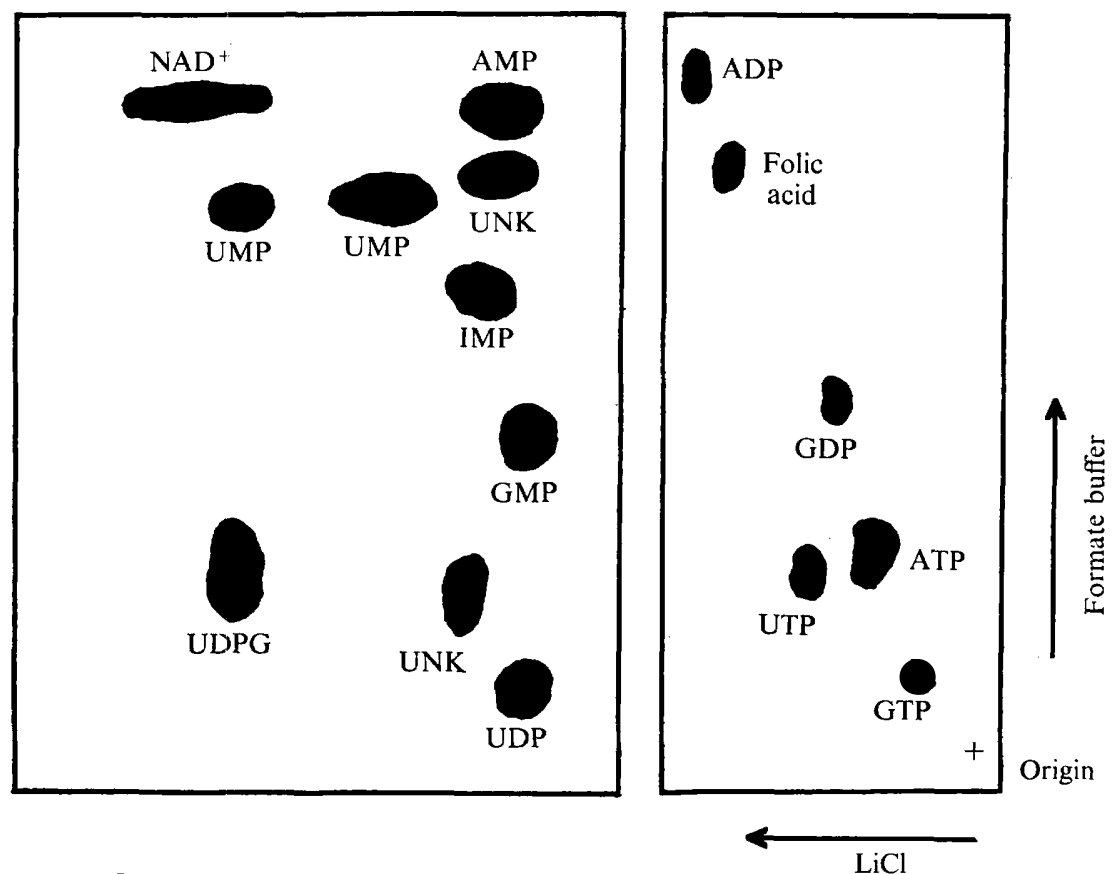

Fig. I. Identification of nucleotides and nucleotide sugars after two-dimensional chromatography. The chromatogram was developed in the first dimension with $0 \cdot 2 \mathrm{M}-\mathrm{LiCl}$ for $2 \mathrm{~min}$, with $\mathrm{r} \cdot \mathrm{O} \mathrm{M}-\mathrm{LiCl}$ for $6 \mathrm{~min}$, and finally with $\mathrm{I} \cdot 6 \mathrm{M}-\mathrm{LiCl}$ to the top of the sheet. After drying and soaking in absolute methanol for $10 \mathrm{~min}$ the thin-layer plate was cut into two sections as shown in the Figure. The section shown on the left was developed in $0.5 \mathrm{M}$-formate buffer, $\mathrm{pH}_{3} .4$, the section on the right in $4 \mathrm{M}$-formate buffer, $\mathrm{pH}_{3} \cdot 4$. Compounds were located by their fluorescence under u.v. light. The Figure is a tracing of a representative experiment. Abbreviations: GTP, guanosine triphosphate; GDP, guanosine diphosphate; GMP, guanosine monophosphate; ATP, adenosine triphosphate; ADP, adenosine diphosphate; AMP, adenosine monophosphate; UTP, uridine triphosphate; UDP, uridine diphosphate; UMP, uridine monophosphate; IMP, inosine monophosphate; UDPG, uridine-5'-diphosphoglucose; $\mathrm{NAD}^{+}$, nicotinamide-adenine dinucleotide; UNK, unknown.

when labelled adenine, guanine, or uracil was added to a cell suspension (all the other compounds which were identified were labelled by at least one of the radioactive bases). On the basis of these characteristics the compound was judged to be a folic acid derivative although exact identification was not attempted.

When labelled adenine was incubated with the cells, radioactivity was found in the adenine nucleotides (ATP, ADP, AMP, NADP + ) in inosine monophosphate (IMP) and in the guanine nucleotides (GTP, GDP, GMP). Labelled guanine and uracil were incorporated only into their respective nucleotides or nucleotide sugars during the period of incubation.

\section{Incorporation patterns of ATP, GTP and UTP in the presence of labelled bases}

Figure 2 shows the incorporation patterns of ATP, GTP and UTP at the pseudoplasmodium stage of development. Cell suspension $(4 \mathrm{ml} ; 0.4 \mathrm{ml}$ packed organisms) was incubated in the presence of $0.04 \mu \mathrm{mol}($ Io $\mu \mathrm{M})$ of $\left[{ }^{14} \mathrm{C}\right]$ adenine $(52 \mathrm{mCi} / \mathrm{mmol}),\left[{ }^{14} \mathrm{C}\right]$ guanine $(52 \mathrm{Ci} /$ $\mathrm{mmol})$ or $\left[{ }^{14} \mathrm{C}\right]$ uracil $(56 \cdot 3 \mathrm{mCi} / \mathrm{mmol})$. Cytosine nucleotides were not present in high enough concentrations for accurate measurement. The initial rate of labelled uracil incorporation nto UTP was only about $5 \%$ of that of adenine and guanine into ATP and GTP. The 


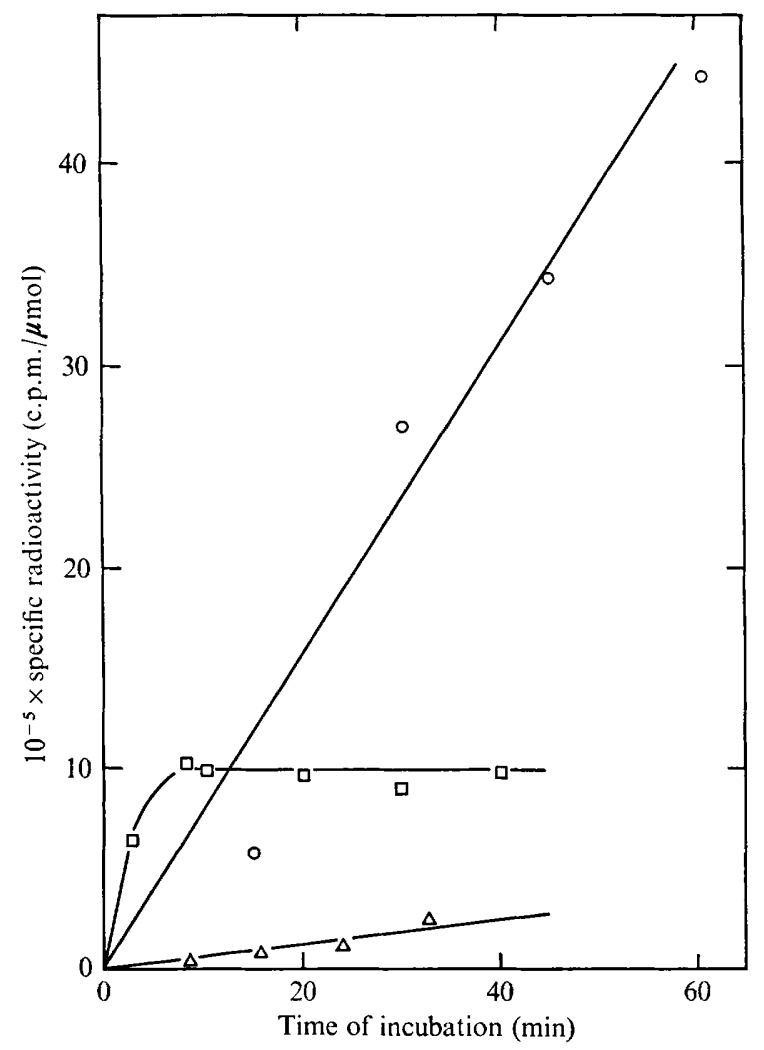

Fig. 2. Incorporation patterns of nucleoside triphosphates. We added $0.04 \mu \mathrm{mol}$ each of $\left[{ }^{14} \mathrm{C}\right]$ adenine $(52 \mathrm{mCi} / \mathrm{mmol}),\left[{ }^{14} \mathrm{C}\right]$ guanine $(52 \mathrm{mCi} / \mathrm{mmol})$ and $\left[{ }^{14} \mathrm{C}\right]$ uracil $(56.3 \mathrm{mCi} / \mathrm{mmol})$, in separate incubation flasks, to $4 \mathrm{ml}$ of organism suspension $(0.4 \mathrm{ml}$ packed cell volume) taken at the pseudoplasmodium stage of development. Nucleotides were isolated from acid-soluble extracts of cells, as described in Methods. O, Specific radioactivity of ATP; $\square$, specific radioactivity of GTP; $\triangle$, specific radioactivity of UTP.

differences in the initial rates of incorporation probably reflect the permeability of the cell membrane to the three nucleotide bases, rather than actual differences in the rate of turnover of the nucleoside triphosphate. We have shown previously (Rutherford \& Wright, 197I) that for both $\left[{ }^{14} \mathrm{C}\right]$ adenine and $\left[{ }^{32} \mathrm{P}\right] \mathrm{Pi}$ the incorporation of isotope into nucleotides is limited by its transport across the cell membrane.

The plateau curve obtained for GTP incorporation was not related to its cellular concentration, as the pool sizes of UTP and GTP are similar. Furthermore, the organism density and the concentration of the three bases in the incubation medium were the same for the three nucleotides.

Comparison of the radioactivity in the incubation medium and that associated with the organisms during incubation in the presence of free bases

The labelling patterns of nucleoside triphosphates observed in Fig. 2 also occurred at all later stages of differentiation. The relationship between the amount of free base in the medium and that associated with the organisms was therefore measured. When organisms at the culmination stage of development were incubated with labelled adenine there was a slow loss of radioactivity from the medium (Fig. 3) and a nearly linear rate of uptake by 


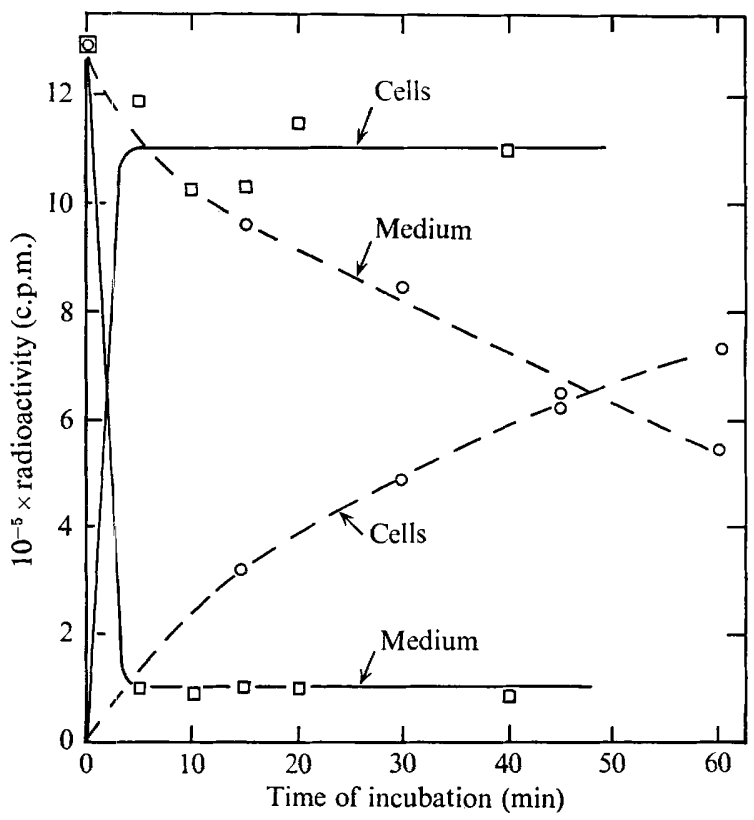

Fig. 3. Comparison of the radioactivity of medium and organisms during incubation in the presence of $\left[{ }^{14} \mathrm{C}\right]$ adenine or $\left[{ }^{14} \mathrm{C}\right]$ guanine. We added $0.04 \mu \mathrm{mol}$ of the labelled base to $3 \mathrm{ml}$ of suspension $\left(0.33 \mathrm{ml}\right.$ packed organisms) at the culmination stage of development. $\mathrm{O},\left[{ }^{14} \mathrm{C}\right] \mathrm{adenine} ; \square$, $\left[{ }^{14}\right.$ C]guanine.

Table I. Distribution of radioactivity during incubation of cells in the presence of $\left[{ }^{14} \mathrm{C}\right]$ guanine

\begin{tabular}{|c|c|c|c|c|c|}
\hline $\begin{array}{c}\text { Time of } \\
\text { incubation } \\
\text { (min) }\end{array}$ & $\begin{array}{c}\mathrm{IO}^{-5} \times \mathrm{PCA} \\
\text { soluble } \\
\text { (c.p.m.) }\end{array}$ & $\begin{array}{c}\mathrm{IO}^{-5} \times \mathrm{PCA} \\
\text { insoluble } \\
\text { (c.p.m.) }\end{array}$ & $\begin{array}{c}\mathrm{IO}^{-3} \times \mathrm{GDP} \\
\text { (c.p.m.) }\end{array}$ & $\begin{array}{c}\mathrm{IO}^{-3} \times \mathrm{GTP} \\
\text { (c.p.m.) }\end{array}$ & $\begin{array}{c}10^{-5} \times 2^{\prime}, 3^{\prime}- \\
\text { GMP (RNA) } \\
\text { (c.p.m.) }\end{array}$ \\
\hline 5 & $1 \cdot 60$ & 0.46 & I. 08 & $2 \cdot 46$ & 0.17 \\
\hline IO & $I \cdot 26$ & 0.95 & 0.85 & 2.00 & 0.46 \\
\hline I 5 & I.05 & $1 \cdot 35$ & 0.70 & $1 \cdot 58$ & 0.90 \\
\hline 20 & 0.87 & $1 \cdot 62$ & 0.49 & 0.92 & $1 \cdot 04$ \\
\hline 40 & 0.71 & $\mathrm{I} \cdot 38$ & 0.15 & 0.27 & I.08 \\
\hline
\end{tabular}

$\left[{ }^{4} \mathrm{C}\right.$ lguanine $(0.004 \mu \mathrm{mol})$ was added to $4 \mathrm{ml}$ of suspension $(0.28 \mathrm{ml}$ packed cells) at the early sorocarp stage of development. The PCA-insoluble counts refer to the radioactivity released from the acid-insoluble material after hydrolysis in $0.3 \mathrm{~N}-\mathrm{KOH}$ for $18 \mathrm{~h}$ at $37^{\circ} \mathrm{C}$. Heating the remaining pellet at $100^{\circ} \mathrm{C}$ for $18 \mathrm{~min}$ did not release additional radioactivity. $2^{\prime}, 3^{\prime}$-GMP was released from the PCA-insoluble material after hydrolysis. GTP and GDP were isolated from the acid-soluble fraction.

the organisms. Conversely, for organisms incubated with labelled guanine the radioactivity in the medium and that associated with the organisms was constant after five minutes (Fig. 3), at about tenfold higher than the extracellular level. This difference in adenine and guanine uptake undoubtedly contributes to the differences observed between the incorporation of their respective nucleoside triphosphates.

\section{Distribution of radioactivity after incubation of organisms in the presence of $\left[{ }^{14} \mathrm{C}\right]$ guanine}

Table I shows the distribution of radioactivity in each component of the incubation mixture, a slow loss of radioactivity from the PCA-soluble fraction being concomitant with 


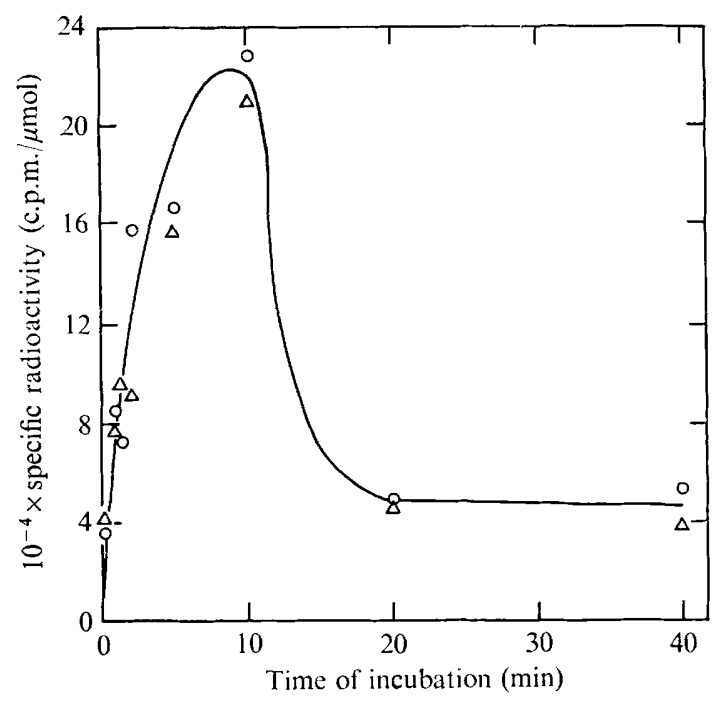

Fig. 4. Incorporation patterns of GTP and GDP. We added $0.004 \mu \mathrm{mol}\left[{ }^{14} \mathrm{C}\right]$ guanine to $4 \mathrm{ml}$ of suspension $(0.62 \mathrm{ml}$ packed organisms) at the late culmination stage of development. $O$, Specific radioactivity of GDP; $\triangle$, specific radioactivity of GTP.

a corresponding uptake of radioactivity into the PCA-insoluble fraction. The sum of the two fractions was essentially constant with time. Of the radioactivity in the acid-insoluble fractions, about $60 \%$ was accounted for in the $2^{\prime}, 3^{\prime}$-GMP resulting from RNA hydrolysis. The only nucleotide labelled in the RNA hydrolysate was $2^{\prime}, 3^{\prime}$-GMP.

The percentage contribution of the guanine nucleotides to the total soluble radioactivity was also investigated. The combined GTP and GDP radioactivity was about $\mathrm{I} \%$ of the total radioactivity in the acid-soluble fraction. The remainder of the radioactivity originally associated with the acid-soluble fraction was found in the methanol wash of the thin-layer chromatography sheets used before the first-dimensional chromatography. In order to identify this radioactive component, the methanol wash was concentrated to $\mathrm{I} \mathrm{ml}$ by evaporation at room temperature under a stream of nitrogen. A sample $(20 \mathrm{ml})$ of this solution was then applied to Whatman No. I filter paper and chromatographed in the following solvents: isopropenol: $\mathrm{HCl}$ : water $(65: 16 \cdot 6: 18 \cdot 4$, by vol.); isopropenol: $2 \mathrm{~N}-\mathrm{HCl}(65: 35$, $\mathrm{v} / \mathrm{v})$; butanol:acetic acid:water (25:4:10, by vol.). The one radioactive spot found was identified as guanine on the basis of the similarity of $R_{F}$ values between the unknown and authentic guanine, and of the shape of the fingerprint (Roberts et al. 1963) after autoradiography.

Incorporation patterns in the presence of low concentrations of labelled guanine

Figure 4 shows the incorporation of labelled guanine into GTP and GDP. By using low levels of exogenous base, the amount of label available to the internal nucleotide pools and to RNA is limited. Therefore, cycling of radioactivity between precursor and product, if it occurs, can be readily studied without the complexity of additional uptake from the medium. Figure 4 shows that after an initial period of uptake, the radioactivity associated with the nucleotides fell to an intermediate plateau value. The incorporation of GMP is not shown because the level was too low to measure accurately. The incorporation curves for GTP and GDP are identical, indicating a very rapid equilibration between these two 


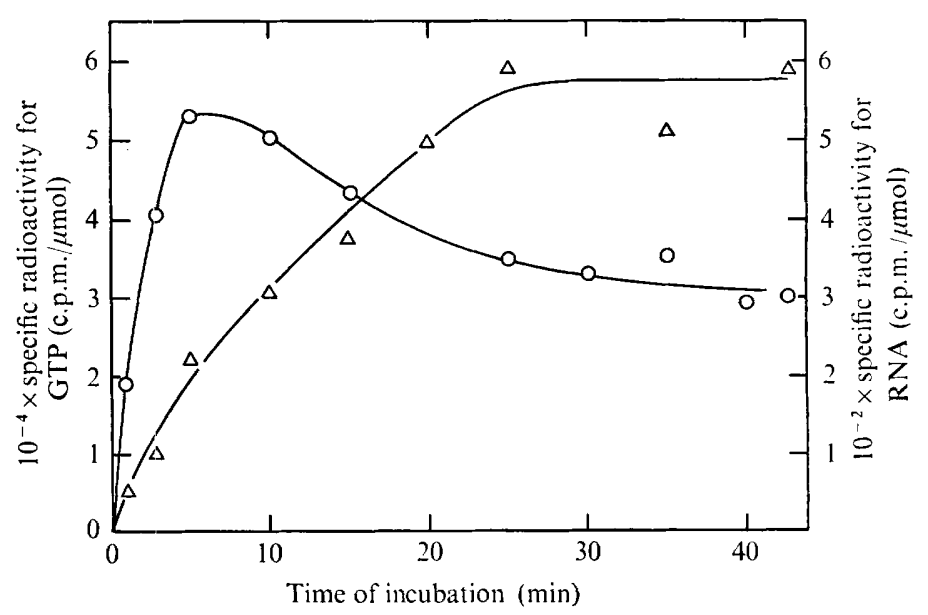

Fig. 5. Incorporation of $\left[{ }^{14} \mathrm{C}\right]$ guanine into GTP and RNA $\left(2^{\prime}, 3^{\prime}-\mathrm{GMP}\right)$. We added $0.004 \mu \mathrm{mol}$ of $\left[{ }^{14} \mathrm{C}\right.$ lguanine to $4 \mathrm{ml}$ of suspension $(0.58 \mathrm{ml}$ packed organisms) at the culmination stage of development. $O$, Specific radioactivity of GTP; $\triangle$, specific radioactivity of $2^{\prime} 3^{\prime}$-GMP resulting from RNA hydrolysis. Note that the values for GTP are 100 times those for RNA.

pools. Similar incorporation curves (not shown) were found for the incorporation of labelled uracil into UTP and for labelled adenine into ATP.

In the analysis of the precursor-product relationship between nucleotides and RNA, guanine was used as the precursor because it is incorporated only into guanine nucleotides. Labelled adenine, on the other hand, is incorporated into both adenine and guanine nucleotides, as well as into inosine monophosphate, while uracil labelling is complicated by incorporation into a large pool of UDPG, as well as the uridine nucleotides. In addition both GTP and GDP were widely separated from other nucleotides during chromatography. Thus, errors in determining pool sizes or specific radioactivity was minimized and mathematical analysis greatly simplified in the case of guanine labelling.

Figure 5 shows the pattern of incorporation of low levels of $\left[{ }^{14} \mathrm{C}\right]$ guanine into GTP and into $2^{\prime}, 3^{\prime}$-GMP after RNA hydrolysis. The shapes of the curves indicate a typical productprecursor relationship between GTP and RNA respectively. Label was rapidly incorporated into GTP until the supply of guanine from the medium was exhausted. Labelled material was then lost from the precursor GTP pool to the product RNA, until a constant value was reached at a specific radioactivity of about $3.3 \times 10^{4}$ c.p.m. $/ \mu \mathrm{mol}$. After a short lag, RNA increased in specific radioactivity, then reached a plateau value of about $5.7 \times 10^{2}$ c.p.m. $/ \mu$ mol. These incorporation curves were obtained in eight separate experiments; in each case a constant plateau value for GTP and RNA was found, although the peak specific radioactivity value for GTP varied from experiment to experiment. Similar results were obtained when using $\left[{ }^{14} \mathrm{C}\right]$ guanosine as the precursor.

To determine whether the incubation conditions produced a progressive impairment of RNA synthesis, a to min pulse of $\left[{ }^{14} \mathrm{C}\right]$ guanine was added, successively, to each of Io flasks shaken from Io to $100 \mathrm{~min}$. The resulting equilibrium specific radioactivities between GTP and RNA did not change significantly. Cells incubated under these conditions differentiate normally when removed to a solid surface (Marshall et al. 1970).

Weber \& Rubin (1970) have shown that the rate of incorporation of $\left[{ }^{3} \mathrm{H}\right]$ uridine into RNA by chick embryo fibroblasts and mouse $3 \mathrm{~T}_{3}$ cells is reduced, as a function of increased cell density. We therefore tested whether the amount of cells per incubation solution 
could affect the percentage of RNA turnover. The cells were harvested from agar sheets in the usual manner and the packed cell volume determined. Bonner's (I947) 'standard solution' was then added to give packed cell volumes ( $\mathrm{ml}$ packed cells $/ \mathrm{ml}$ cell suspension) of $0.045,0.090$ and 0.150 . Portions $(4 \mathrm{ml})$ of each suspension were then added to rotating flasks and incubated with labelled guanine as described previously. Although the specific radioactivity of both the precursor and the product were higher for the samples with low cell density than for samples with high cell density, there was no difference in the shape of the incorporation curves. Thus, the density of cells in the incubation flasks did not affect the conclusions to be derived from the incorporation curves.

\section{Long-term incubation studies during differentiation of $D$. discoideum on filter paper discs}

The incorporation kinetics between GTP and RNA were also studied under conditions in which normal differentiation occurred. Organisms were incubated with $\left[{ }^{14} \mathrm{C}\right]$ guanine in separate Petri dishes as described in Methods, and the nucleotides were isolated at appropriate times. The resulting incorporation curves for the incubations in shaking flasks (Fig. 5) and those on filter paper were similar. In both cases a peak in the specific radioactivity of GTP occurred as precursor was exhausted from the medium, followed by a loss of radioactivity to RNA. Likewise, in both incubation procedures GTP and RNA reached constant specific radioactivities. Incubation under liquid conditions was used routinely, as this method is technically easier.

\section{Test of the significance of bacterial contamination on the in vivo incorporation patterns}

Experiments were designed to test whether bacteria, associated with washed slime mould organisms, could contribute to the incorporation of label into either GTP or RNA. Organisms were harvested from agar sheets and washed three times in cold sterile distilled water by centrifuging at $1000 \mathrm{~g}$. After the final wash, half the organisms were plated onto Petri dishes containing non-nutrient agar, and the other half onto Petri dishes containing non-nutrient agar plus streptomycin sulphate $(0.5 \mathrm{mg} / \mathrm{ml})$. The organisms were allowed to differentiate to the culmination stage, then were washed from the agar with $4 \mathrm{ml}$ of sterile Bonner's solution buffered with 2-( $N$-morpholino)-ethanesulphonic acid. A sample of the suspension was removed for bacterial counting and the remainder incubated for $40 \mathrm{~min}$ with radioactive guanosine. Although the streptomycin treatment reduced the level of remaining bacteria from $5 \times 10^{4}$ cells $/ \mathrm{ml}$ to less than $\mathrm{I} \times 10^{2}$ cells $/ \mathrm{ml}$, there was no change in the specific radioactivities of either GTP or RNA. In fact, bacterial contamination significantly contributed to the results of incorporation studies only when the level of bacteria reached $\mathrm{I} \times 10^{7} / \mathrm{ml}$ in the incubation suspension. This is the same level of bacteria for measurable incorporation of uridine into RNA as that found by Hirschberg et al. (1968).

We also tested whether the numbers of bacteria present at the culmination stage had any effect on the overall incorporation curves. Organisms were allowed to differentiate in the presence and absence of streptomycin as described above, then harvested and incubated in the presence of label. Similar incorporation curves were obtained in both streptomycintreated organisms and in controls.

Development of a computer model for analysis of nucleotide and RNA turnover

A computer model of the observed precursor-product relationship between nucleotides and RNA was developed in order to determine the flux rate in vivo between nucleotides and 


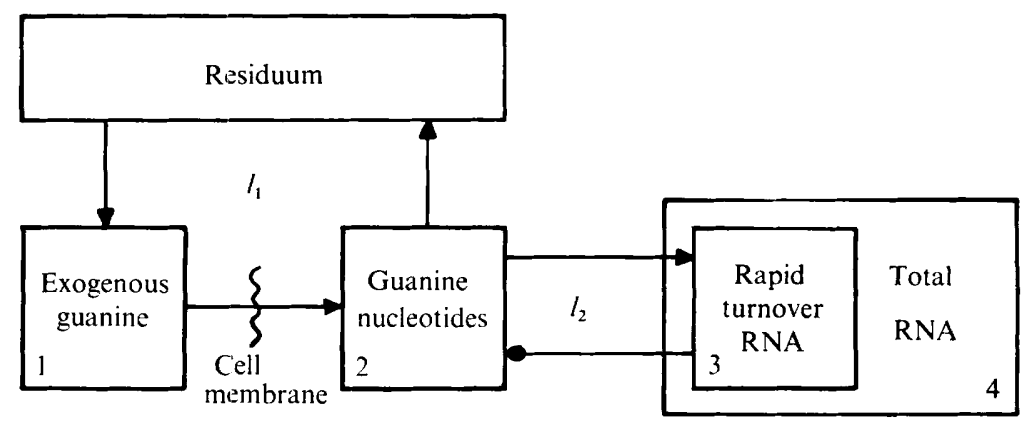

Fig. 6. Model of precursor-product relationships between nucleotides and RNA.

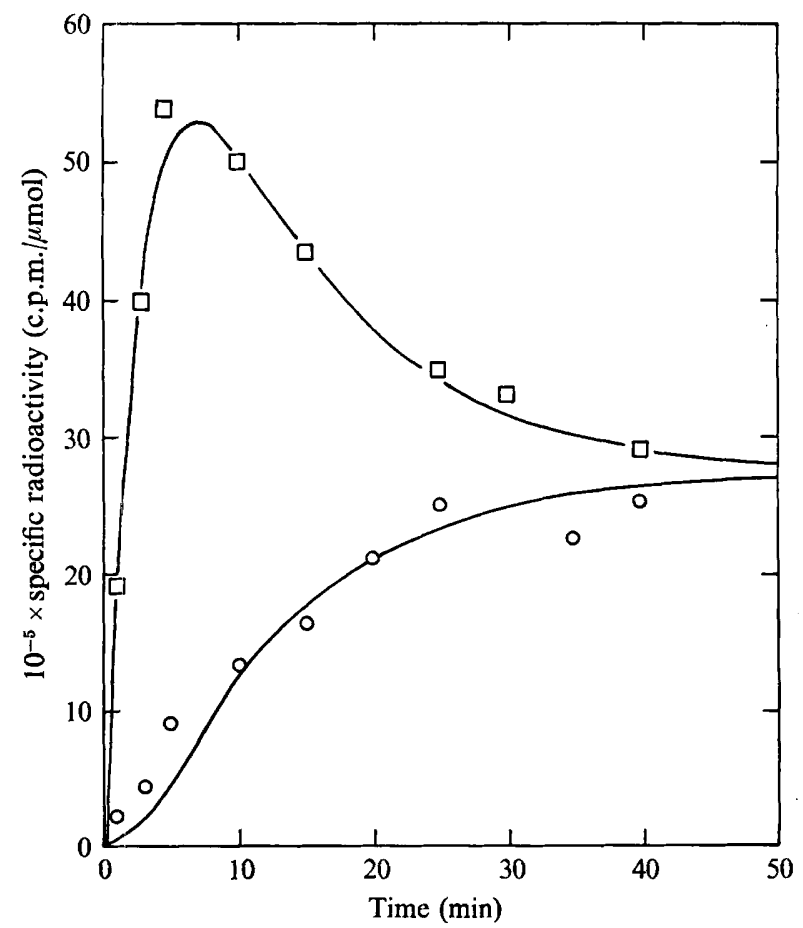

Fig. 7. Best fit to the guanine nucleotide-RNA radioactive tracer experiment using the model in Fig. 6. The specific radioactivities of RNA have been multiplied by 43.0 to account for the compartmentalization of the RNA pool. $\square$, Measured nucleotide specific radioactivities; $O$, measured RNA specific radioactivities multiplied by the compartment factor.

RNA, the percentage of RNA which was undergoing rapid turnover, and the rate of turnover of this RNA. The calculations were performed on an IBM-360, Model 65, computer using a program, TRACER, developed by Park. TRACER is written in the programming language $\mathrm{PL} / \mathrm{I}$, requires $\mathrm{I} 50$ bytes of core storage, and is a general purpose program for the analysis of tracer flow in steady state systems.

The model which was used to represent the experimental data (Fig. 6) assumes that the metabolite pools remain constant in size during the experiment; this has been demonstrated experimentally for RNA and the nucleotide pools (Pannbacker, 1966, 1967; Rutherford \& Wright, 1971). In accord with this assumption the chemical fluxes, expressed as $\mathrm{mm} / \mathrm{min}$ 
Table 2. Calculated parameters for guanine-RNA experiment using the model

$\begin{array}{ll}\text { Rapid turnover RNA concn }\left(C_{3}\right) & 0.12 \mathrm{mM} \\ \text { RNA in rapid turnover pool } & 2.3 \% \\ \text { Extracellular guanine concn referred to cell volume } & 4.54 \times 10^{-5} \mathrm{~mm} \\ \text { Chemical flux loop I }\left(l_{1}\right) & 1.472 \times 10^{-5} \mathrm{~mm} / \mathrm{min} \\ \text { Chemical flux loop } 2\left(l_{2}\right) & 3.91 \times 10^{-3} \mathrm{~mm} / \mathrm{min} \\ \text { Turnover time of nucleotide pool } & 18 \mathrm{~min} \\ \text { Turnover time of rapid RNA pool } & 30 \mathrm{~min}\end{array}$

(mmol/l packed cells/min) always appear as flux loops $\left(l_{1}\right.$ and $\left.l_{2}\right)$. The intracellular guanine nucleotide pool is actually composed of three pools (GMP + GDP + GTP) which turn over among themselves so rapidly that they reach radioactive equilibrium within seconds (Fig. 4), a short time compared with any significant measurement interval in the experiment. In addition, the exogenous or extracellular guanine pool is initially radioactive and all other pools are initially unlabelled.

The guanine RNA pool in the model is composed of two fractions. One fraction, called the rapid turnover RNA, exchanges with the nucleotide pool via the flux loop $l_{2}$, the other fraction comprises the remainder of the RNA pool. The latter fraction has no exchange with the nucleotide pool and hence remains non-radioactive. In the model, $C_{3}$ is the concentration of the rapid turnover RNA, $C_{4}$ is the total RNA concentration.

Figure 7 shows the best fit of computer-generated curves to the experimental data. The curves were obtained after optimizing the flux loops and adjusting the size of the RNA pool undergoing turnover to the correct RNA specific radioactivity at equilibrium. The parameters resulting from this analysis are shown in Table 2. The concentration of RNA undergoing rapid turnover was about $0.12 \mathrm{mM}$, or $2 \%$ of the total RNA. The time required for this pool of RNA to turn over was about $30 \mathrm{~min}$.

\section{DISCUSSION}

The rate of RNA turnover in Dictyostelium discoideum has been estimated previously by several different methods (Hirschberg et al. I968; Inselburg \& Sussman, I967; Pannbacker, 1967). However, the percentage of the RNA pool which is undergoing turnover at a particular stage of differentiation has not been accurately determined, primarily because of the lack of an appropriate method for determining this parameter. We have found that a small, rapidly turning over pool of RNA can be detected by using low concentrations of radioactive precursor and following the incorporation pattern of precursor nucleotide and product RNA as radioactive equilibrium occurs. By using low concentrations of radioactive precursors it is possible to attain isotopic equilibrium values for precursor and product. The cell acts as a closed system, since no net radioactivity is lost from the precursor or from the product during the rather short incubation period (Table I). Thus, the distribution of radioactivity between precursor and product and the resulting incorporation curves are direct reflections of the interconversion of internal pools.

The method for determining the percentage of the RNA which is turning over can best be seen by comparing the incorporation curves for material in which the total RNA pool is turning over and for that in which only a small fraction of the RNA pool is turning over. Figure 8(a) shows the expected incorporation curves when the entire product pool is turning over. The precursor released by degradation of the product would be re-utilized in the synthesis of the product. In this case of total product turnover, the precursor and product 

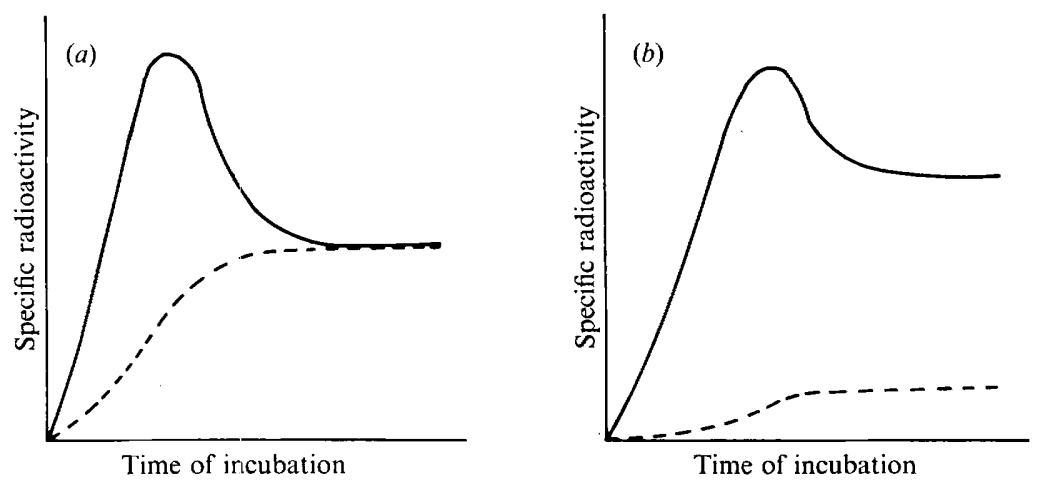

Fig. 8. Schematic incorporation curves of radioactive precursor into GTP and $2^{\prime}, 3^{\prime}$-GMP (RNA). (a) Incorporation resulting from complete turnover of the RNA pool. (b) Incorporation resulting from partial turnover of RNA pool. In both $(a)$ and $(b)$ the precursor released by the degradation of the product would be utilized in the resynthesis of the product. ——, Specific radioactivity of GTP; --_--, specific radioactivity of $2^{\prime}, 3^{\prime}-$ GMP (RNA).

come to the same equilibrium specific radioactivity. Figure $8(b)$ shows the incorporation curve when only a small percentage of the total RNA pool is turning over. The portion of the RNA pool undergoing turnover also comes into equilibrium with the precursor. However, when the organism is ruptured before isolation of the RNA, both the radioactive pool of RNA (turnover RNA) and the non-radioactive pool are mixed. The resulting specific radioactivity of the total pool is therefore lower than that of the 'turnover RNA' owing to the large pool of unlabelled RNA. Thus, the equilibrium specific radioactivity as shown in the examples in Figs. 8 and 5 indicates the percentage of the RNA pool which is turning over.

These methods do not distinguish the type of RNA undergoing turnover. For example, we cannot conclude that this 'turnover RNA' is DNA-like heterogeneous RNA. Nevertheless, the value of $2 \%$, for the fraction of RNA undergoing turnover in $30 \mathrm{~min}$, is well within the corresponding literature values (Kijima \& Wilt, I969; Leighton \& Doi, I97I; Nierlich \& Vielmetter, 1968; Salser, Janin \& Levinthal, I968; Watts, 1964). This turnover time is also similar to that required for the synthesis and transport of nuclear RNA to the cytoplasm of $D$. discoideum. Kessin (1973) has shown that ribosomal RNA species appear in the cytoplasm 6 to $7 \mathrm{~min}$ after the onset of labelling of vegetative cells of $D$. discoideum, and after $30 \mathrm{~min}$ only $10 \%$ of the label remains associated with the nucleus. In developing organisms, RNA appears in the cytoplasm at a reduced rate. Similar results were obtained by Firtel \& Lodish (1973). Under conditions in which the synthesis of rRNA was inhibited, cells were pulse labelled for I min with $\left[{ }^{3} \mathrm{H}\right]$ uracil. After a subsequent $20 \mathrm{~min}$ chase period, $8 \%$ of the radioactivity remained in the nucleus, while the majority of label appeared in the cytoplasm.

To develop a valid model of precursor-product interactions, the distribution of radioactivity associated with all components of the incubation system must be determined. We found, for example, that within $5 \mathrm{~min}$ of exposure to labelled guanine, at least $90 \%$ of the label was associated with the organisms (Fig. 3). During further incubation, radioactivity was lost from the acid-soluble fraction into RNA (Table I). Although $99 \%$ of the radioactivity remaining in the acid-soluble fraction during the incubation period is apparently free guanine, the shape of the incorporation curve for GTP and RNA is typical of a system in which the radioactive precursor has been exhausted from the medium. Therefore, a large portion of the guanine added to the medium must be metabolically inaccessible to the 
GTP and RNA pools during the incubation period. This inaccessibility could result from the ionic properties of the cell membrane, resulting in binding of extracellular guanine. This is suggested from the rapid association of radioactivity with the cells as shown in Fig. 3 . Alternatively, the radioactive guanine may permeate the cell, but most of it may be 'trapped' in a compartment inaccessible to the GTP-RNA system.

The experimental data are consistent with models in which the degradation products of RNA re-enter the nucleotide pool. This interpretation is supported by the recent work of Hurlbert \& Hardy (1972), who showed that in rat liver nuclei most of the degradation of heterogeneous RNA is via 5 '-nucleotides which may be reutilized for RNA synthesis. Since the rapid turnover fraction of RNA is probably heterogeneous, perhaps what is measured is an average of many smaller pools turning over at different rates. However, in fitting a kinetic model to the experimental data it is appropriate to use as simple model as possible, consistent with the data. A number of more complicated models were seriously considered, but did not improve the fit to the data. This does not mean that nucleotide and RNA metabolism is not more complex than is shown by the model used. Nevertheless, by using the model and optimizing the flux loops and adjusting the percentage of RNA turnover to give the correct RNA specific radioactivity when radioactive equilibrium has been achieved, a fit to the data shown in Fig. 7 was obtained.

The modelling of the extracellular guanine pool requires special discussion. This extracellular precursor is distributed in the volume of the suspension, rather than within the organism volume, so its concentration must be referred to the cell volume. (The extracellular volume was approximately Io times the cell volume.) In addition, only part of the extracellular guanine is converted to the intracellular guanine-nucleotide pool (Table 1 ). Lastly, the extracellular guanine pool may not remain constant in size during the time of incubation, but may be completely taken up by the organism. This situation has been approximated in the model (Fig. 6) by using an extracellular pool whose radioactivity decreases during the period of incubation. Hence, there is a flux loop, $l_{1}$, which is completed through a residuum pool. The residuum pool is of infinite size, thus accepting radioactive molecules but returning only non-radioactive molecules. The extracellular guanine pool is 1000 times smaller than the intracellular nucleotide pool, so that even if the extracellular guanine pool were taken up by the intracellular nucleotide pool, its effect on pool size would be negligible.

To interpret radioactive tracer experiments it is important to make a kinetic model of the experiment which is as explicit and complete as possible. Such models also help to avoid errors in interpreting experimental data. For example, it is not correct simply to use the specific radioactivity of the extracellular base or of the acid-soluble fraction as a precursor function for the RNA. In the case of the experiment shown in Table I, much of the extracellular base did not participate in the experiment. The acid-soluble fraction contains these 'inactive' bases as well as those participating as RNA precursors. The extracellular precursor specific radioactivity is not equal to the intracellular product specific radioactivity in the case of GTP in the present analysis, UTP and UDPG (Pannbacker, 1967), or methionine (Wright \& Anderson, I960). Thus, rates of synthesis calculated on the basis of the specific radioactivity of the added extracellular precursor are not valid.

We are grateful to Mr J. Strawhorn for preparing the cell cultures. This investigation was supported by Public Health Service grants HDo0288 and HD05357 from the National Institute of Child Health and Human Development. 


\section{REFERENCES}

Barravecchio, J., Baumann, P. \& Wright, B. E. (1969). Cell volume determinations of Dictyostelium discoideum. Journal of Appiied Microbiology 17, 64I-644.

BONNER, J. T. (I947). Evidence for the formation of cell aggregates by chemotaxis in the development of the slime mold Dictyostelium discoideum. Journal of Experimental Zoology 106, I-26.

Ceccarini, C. \& Filosa, M. (1965). Carbohydrate content during development of the slime mold, Dictyostelium discoideum. Journal of Cellular and Comparative Physiology 66, 135-1 39.

CowiE, D. B. \& Bolton, E. (1957). The use of metabolic pools of purine compounds for nucleic acid synthesis in yeast. Biochimica et biophysica acta $25,292-298$.

FirTel, R. A. \& Lodish, H. F. (1973). A small nuclear precursor of messenger RNA in the cellular slime mold Dictyostelium discoideum. Journal of Molecular Biology 79, 295-314.

Gustafson, G. L. \& WRIGHT, B. E. (I972). Analysis of approaches used in studying differentiation of the cellular slime mold. In Critical Reviews of Microbiology, vol. I, pp. 453-478. Edited by A. I. Laskin and H. Lechevalier. Cleveland, Ohio: CRC Press.

Hirschberg, E., Ceccarini, C., Osnos, M. \& Carchman, R. (i968). Effects of inhibitors of nucleic acid. and protein synthesis on growth and aggregation of the cellular slime mold Dictyostelium discoideum Proceedings of the National Academy of Sciences of the United States of America 6r, 316-323.

Hurlbert, R. B. \& HARdy, D. (1972). Turnover of Hn RNA and PolyA in rat liver nuclei. Federation Proceedings 3I, 428-430.

InSELbURG, J. \& Sussman, M. (1967). Incorporation of ${ }^{3} \mathrm{H}$-uridine into RNA during cellular slime mould development. Journal of General Microbiology 46, 59-64.

KESSIN, R. H. (1973). RNA metabolism during vegetative growth and morphogenesis of the cellular slime mold Dictyostelium discoideum. Developmental Biology 31, 242-25I.

KiJimA, S. \& WILT, F. H. (1969). Rate of nuclear ribonucleic acid turnover in sea urchin embryos. Journal of Molecular Biology 4o, 235-246.

LeIGHTon, T. J. \& Dor, R. H. (I97I). The stability of messenger ribonucleic acid during sporulation in Bacillus subtilis. Journal of Biological Chemistry 246, 3189-3195.

Marshall, R., SARgent, D. \& Wright, B. E. (1970). Glycogen turnover in Dictyostelium discoideum. Biochemistry 9, 3087-3094.

Newell, P. C., Telser, A. \& Sussman, M. (1969). Alternative developmental pathways determined by environmental conditions in the cellular slime mold Dictyostelium discoideum. Journal of Bacteriology 100, 763-768.

Nierlich, D. P. \& Vielmetter, W. (I968). Kinetic studies on the relationship of ribonucleotide precursor pools and ribonucleic acid synthesis. Journal of Molecular Biology 32, I 35-147.

Pannbacker, R. G. (1966). RNA metabolism during differentiation in the cellular slime mold. Biochemical and Biophysical Research Communications 24, 340-345.

Pannbacker, R. G. (1967). Uridine diphosphate biosynthesis during differentiation in the cellular slime mold. I. In vivo measurements. Biochemistry 6, $1283-1286$.

Plagemann, P. G. W. (I97I). Nucleotide pools of Novikoff hepatoma cells growing in suspension culture. II. Independent nucleotide pools for nucleic acid synthesis. Journal of Cellular Physiology 77, 24 I-258.

PlagemanN, P. G. W. (1972). Nucleotide pools of Noviloff hepatoma cells growing in suspension culture. III. Effects of nucleosides in medium on levels of nucleotides in separate nucleotide pools for nuclear and cytoplasmic RNA synthesis. Journal of Cellular Biology 52, I3 I-I46.

RANDERATH, E. \& RANDERATH, K. (I964a). Resolution of complex nucleotide mixtures by two dimensional anion-exchange thin-layer chromatography. Journal of Chromatography 16, I 26-1 29.

RANDERATH, E. \& RANDERATH, K. (I965). Ion-exchange thin-layer chromatography. XII. Quantitative elution and microdetermination of nucleoside monophosphate, ATP, and other nucleotide coenzymes. Analytical Biochemistry 12, 89-93.

RANDERATH, K. \& RANDERATH, E. (I964b). Ion exchange chromatography of nucleotides on poly(ethyleneimine)-cellulose thin layers. Journal of Chromatography I6, I I I-I 25.

Roberts, R., Abelson, P., Cowie, D., Boulton, E. \& Britten, P. (I963). Annual Report of the Director of the Department of Terrestrial Magnetism. Carnegie Institute, Washington, D.C. 607, I90-196.

Rutherford, C. L. \& WRIGHT, B. E. (I97I). Nucleotide metabolism during differentiation in Dictyostelium discoideum. Journal of Bacteriology 108, 269-275.

SAlSER, W., JANIN, J. \& Levinthal, C. (I968). Measurement of the unstable RNA in exponentially growing cultures of Bacillus subtilis and Escherichia coli. Journal of Molecular Biology 3r, 237-266. 
SARGENT, D. \& Wright, B. E. (I97I). Trehalose synthesis during differentiation in Dictyostelium discoideum. II. In vivo flux determinations. Journal of Biological Chemistry 246, 5340-5344.

WATTS, J. W. (1964). Turnover of nucleic acids in a multiplying animal cell. Biochemical Journal 93, 306-3I 2. WEBER, M. J. \& RUBIN, H. (1970). Uridine transport and RNA synthesis in growing and in density-inhibited animal cells. Journal of Cell Physiology 77, I57-168.

WRIGHT, B. E. (1968). An analysis of metabolism underlying differentiation in Dictyostelium discoideum. Annual Conference on Molecular Aspects of Differentiation, Oak Ridge National Laboratory. Journal of Cell Physiology 72, Si, I45-160.

Wright, B. E. \& ANDERSON, M. L. (1960). Protein and amino acid turnover during differentiation in the slime mold. II. Incorporation of ${ }^{35} \mathrm{~S}$ methionine into the amino acid pool and into protein. Biochimica et biophysica acta $43,67-78$. 